\title{
CAPITALIZATION OF INTERNATIONAL UNICORN COMPANIES: TO WHAT EXTENT IS IT REASONABLE?
}

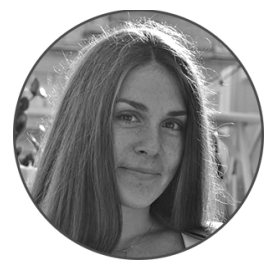

Anastasiya S. BUTUZOVA

Lomonosov Moscow State University, Moscow, Russian Federation

butuzova_nastena@mail.ru

orcid.org/0000-0003-0759-5660

\section{Article history:}

Received 11 December 2017

Received in revised form

25 December 2017

Accepted 16 January 2018

Translated 7 March 2018

Available online 27 March 2018

JEL classification: F21, F36, F41, F63

Keywords: unicorn company, capitalization, IP0, securities market, venture capital

\begin{abstract}
Importance The article addresses unicorn companies as the most successful and fastest-growing start-ups. It analyzes to what extent their capitalization is justified, what prospects for growth they have after IPO, and how they meet investors' expectations.

Objectives The objectives of the study include a comprehensive review of creation and development of unicorn companies, identifying the sources of their growth and credibility of their open market valuation.

Methods The study employs methods of analysis, synthesis, retrospective analysis, comparison, and compilation.

Results The paper shows why unicorns are overvalued in the market. It emphasizes that the possibility and expediency of unicorn capitalization depends on the interests pursued by market actors. The practicability of IPO and its implications also vary from company to company.

Conclusions and Relevance High capitalization of unicorn companies is not reasonably feasible in every instance: investors are often riding on the wave of a boom, after which the value of business falls to zero. However, high-tech and innovative unicorns, on the contrary, are drivers of development and their high capitalization is indeed justified.
\end{abstract}

The editor-in-charge of this article was Irina M. Vechkanova Authorized translation by Irina M. Vechkanova

Exploring the origin of the term unicorn shall precede any studies into the capitalization of companies. In the Middle Ages, a unicorn was believed to be a sign of good luck. Encountering a unicorn, to say nothing about taming it, is also great luck for today's venture investors. The unicorn in their way promises incredible wealth to the lucky one. Unicorns are private startups, which are appraised to be worth more than USD 1 billion and initially financed with venture capital. Such startups undergo one and the same challenge. Their stability and viability are tested when they go public or

\footnotetext{
${ }^{\dagger}$ For the source article, please refer to: Бутузова A.C. Капитализация международных компаний «единорогов»: насколько она оправданна? Финансы и кредит. 2018. Т. 24. № 2. C. $430-438$.

URL: https://doi.org/10.24891/fc.24.2.430
}

larger companies absorb them (in most cases, unicorns benefit more from absorption because larger corporations infuse their resources to further develop the unicorn startup) [1-5]. Here a question arises. Is the capitalization of international unicorns reasonable? What opportunities for growth do companies get after an IPO? Does it meet investors' expectations?

The phenomenon of unicorns originated not so long ago. Three triggers may cause such startups to appear:

1) globalization. The world creates more and more inner ties. Startups with the proven business model scale their business globally using venture capital. For example, Google, Facebook, Whatsapp, Instagram, Uber, AirBnB, etc.; 
2) digital economy. Information products (goods and services) differ from conventional tangibles. If information is transferred, it is still available for the seller, being replicated many times. Information products are sold with almost zero costs. Considerable expenses for development are earmarked for each copy sold. Therefore, the more large scale the project is, the cheaper the product may be. Hence producers are not constrained, tending to dominate the market (if Linkedln is present in the market, other social network for professional will not exist);

3) avoidance of intermediaries. Many unicorns are so successful because they eliminated intermediaries and created the $\mathrm{c} 2 \mathrm{c}$ market model (customer to customer). Any emerging competition makes prices fall dramatically. The flip side of the situation is that it brings requirements of the State and public to such products down (for example, safety and occupational standards in Uber). Public companies are bound to comply with such requirements since they are constantly monitored by supervisory and regulatory bodies, which may easily signal any breaches in legal compliance ${ }^{1}$.

Having settled the origin of the term unicorn, I proceed to statistical data. How many unicorns are there? What industries do they inhabit? How much time does it take a startup to morph into a unicorn? What countries have the most favorable conditions for a unicorn boom? According to Crunchbase, there are 267 unicorns with their total market value amounting to USD 920.8 billion.

\footnotetext{
${ }^{1}$ We may refer to the flamboyant story of Theranos, biotech company, which was appraised as much as USD 9 billion at its prime, but remeasured down to zero. The company was based in the technology for conducting several dozens of analysis using just a drop of the patient's blood. The company grew steadily, received return on investments and managed to raise even more funds after going public. The value of the company was measured with billion scales, though all the information on its operations were kept strictly confidential. The secret attracted new clients and investors within several years. However, journalists of the Wall Street Journal conducted an investigation revealing that the company made its tests using ordinary medical equipment, which was far from being very precise given such tiny amount of blood is taken. Later on, supervisory authorities detected breaches posing patients' life and health at stake. This fact was the basis to recall blood test results made for several years and send new details. Furthermore, the company was found to have taken more than a drop of fingertip blood as it declared. The revaluation brought the company's value to zero. Therefore, the underlying secret was revealed, thereby depriving the company of its target clientele, subsequently ruining the business idea and undermining the initial value the company was allegedly worth.
}

As reported by The Wall Street Journal, as of October 2017, there were 168 unicorn companies. It takes a relevant startup six years on average to become a unicorn. Most unicorns were born in the North America (61.4\%) and Asia, primarily in China (26\%). Growth in the number of unicorns reached its peak in 2014-2015. In 2015, the investment environment was favorable for investors, offering low interest rates. Alibaba, China's e-commerce company, became a pioneering unicorn in 2005. From perspectives of the world economy, it is no surprise it was China where such a company originated since the Chinese market grows, being closed and driven by high-profile companies, though the capital market is insufficiently developed. Most unicorns are concentrated in e-commerce and software development (Table 1).

What distinguishes unicorns from other companies is the time it takes them to reach the value of USD 1 billion. Jet.com, U.S. trade company, is a prominent example as its value reached the respective amount in a four months' time after its incorporation. The company operates in e-commerce and focuses on more thrifty buyers, who seek lower prices more than fast delivery. The reason why Jet.com skyrocketed so quickly was that venture investors got interested in the founder's experience. Before Jet.com, Marc Lore developed and sold Diapers.com to Walmart. Having got a grip of the process, he raised USD 820 million from venture investors to sell Jet.com to Walmart, estimating it to be worth USD 3.3 billion. Until the moment only seven companies managed to turn into unicorns for one year, and other 13 ones pursued so for two years after their incorporation (Table 2).

As for Russia, the small national market (approximately 2 percent of the global IT market in comparison with 40 percent in the USA), long distance from principal global business centers and impossibility to integrate into global technological chains restrict the potential of the Russian technological companies. Escalating tensions in foreign policy affairs affect companies, which seem to have already deserved the global reputation and recognition. For example, Kaspersky Antivirus has been accused of the National Security Agency data leakage, thereby actually losing its share in the U.S. market. After the 2012-2013 peak, startups became less active as the Russian venture capital market went down in 2015 due to the outflow of 
venture capital funds from Russia [6-10]. Belorus sees a similar situation.

Dealing with the capitalization of unicorns, first of all, it is necessary to make it clear that the value of such companies is almost always overestimated. So, unicorns undertake funding rounds, which boost their capital. Investors participate in such funding rounds. Investors consider an IPO as an opportunity to break free from investment and sell their stake. However, it is noteworthy that unicorns shall use as much investment as they really need for their development but not more. When the team spends the raised funds inefficiently, it signals the lowest likelihood of its business success. The hungrier and more able to save money the startup, the higher its competitiveness. However, everything should be in balance in this case since the startup competes with 10 identical rivals. If the startup is hungry, it may lose the race.

The market basically displays no response when there appears a unicorn. If the company is public, its quotations will be higher because it has a good information trail, being more transparent for investors. The quotation will be formed by the market, thus being more unbiased. On the contrary, unicorns are not bound to disclose their performance results unless they are regulated by financial markets. Large stock exchanges require listed companies to present audited financial statement for at least three years. This is one of the reasons why unicorns abstain from going public and IPO.

Second, in certain cases unicorns are reluctant to have an IPO since it is a protracted process generating no benefits for them. The period from the first funding round up to the potential entry may take, on average, about 6-8 years, and 9-10 years until an IPO. Besides, IPO is rather long, and respective bankers' services are rather expensive. As circulated in the investment environment, it is economically unreasonable to go public with quotations lower than USD 100 million. On the one hand, companies undertake an IPO for their liquidity. If the company's shares are deemed valuable in the capital market, there will be demand for them. On the other hand, unprofitable startups (those ones generating income, without deriving profit) face a drop in the quotations of their stocks when they enter the open market. It happens because investors now have another sentiment about the companies' future profit. Furthermore, projected income is higher than the company's quotation in the stock market. High quotations stem from excess capital in the market. When investors hardly have any expectations, stocks will be difficult to sell at a high price. Companies should wait for the IPO window to break open meaning that they may benefit from more favorable macroeconomic conditions. So, if investors have changed their sentiment (worse expectations), an IPO is not reasonable for unicorns.

Third, investment in startups becomes more common nowadays. The modern market inhabited by unicorns has neither securities, nor liquidity. Stocks usually cost as much as buyers are willing to pay for them, while unicorns' stocks are so unusual that it is even hard to imagine where to sell them. That is why the bubble is seen in private investment - in the market, where there are no quotations and liquidity is worse than it was in the stock market of 2000. Why do investors put up their money for unicorns then? The potential and growth opportunities of such companies are the main drivers of their overestimated values. Investors are gazing at startups, which have not been incorporated yet but still have a big potential for growth.

Fourth, overestimated quotations of unicorns may plummet. Even if the quotations are far from being truth, the drop will not entail considerable consequences. Founders and shareholders will not get what they intend to, but it will not be a surprise since the high rate of return always implies high risks. We shall note that investors can afford it during the period of low interest rates. Investment funds will also suffer losses. However, they allocate some part of their assets for alternative investment (venture capital), thereby protecting themselves from tremendous losses. They will see only their yields drop. As for private investors, they generally put up their money for such companies indirectly through mutual investment funds, thus alleviating consequences of the bubble burst. Therefore, the economy will not be seriously affected. However, considering the dot.com crisis (the bubble in the U.S. market in 2000), I shall admit its strong effect leading to the transformation of the venture capital segment.

As a conclusion, I would like to note that every unicorn entrepreneur pursues his/her own interests, which determine whether it is possible or reasonable to capitalize a unicorn startup. It is not always reasonable

Please cite this article as: Butuzova A.S. Capitalization of International Unicorn Companies: To What Extent Is It Reasonable? 
to capitalize unicorn startups. The venture capital segment sets up its rules, which will be mastered only by the strongest contenders. Large venture capital funds search for the potential hype, which would be understandable for everyone and can change the world, i.e. change the way people do things. Financial injections and lobbying warm up the topic, luring new investors. The capitalization reaches the billion level. The startup starts generating earnings. At this point, the unicorn startup had better be sold to a larger company, which would be affected more if the unicorn startup had grown up and become a strong competitor. The probability is low but the successful result may offset investment many times. There is a probability, albeit very little, that the company will go public successfully. However, such cases do exists. In fact, investors need to get on the right side of the founder and persuade him/her to perform as much effectively as possible so that the product in question be placed in the market. The founder therefore tries to retain the majority share and hold levers of the project so as not to be expelled out of his/her own business.

\section{Table 1}

Top 10 unicorn companies as of 2017

\begin{tabular}{llll}
\hline Company & Country & Activity & $\begin{array}{l}\text { Time before reaching } \\
\text { the value of USD 1 billion }\end{array}$ \\
\hline Uber & USA & Transportation & 4 years 6 months \\
\hline ANT Financial & China & Financial services & - \\
\hline Didi Chuxing & China & Internet technology for end users & - \\
\hline Xiaomi & China & Hardware & 1 year 9 months \\
\hline Airbnb & USA & Internet technology for end users & 3 years \\
\hline Space-X & USA & Defense and aerospace industry & 10 years \\
\hline Palantir Technologies & USA & Software & 8 years \\
\hline Toutia0 & China & Internet technology for end users & - \\
\hline WeWork & USA & Real estate & 1 year 6 months \\
\hline Lufax & China & Financial services & 3 years 4 months \\
\hline
\end{tabular}

Source:Authoring, based on TechCrunch website data. URL: https://techcrunch.com/

Table 2

The fastest-growing unicorn companies

\begin{tabular}{|c|c|c|c|c|c|}
\hline Company & Country & Incorporation year & Activity & $\begin{array}{l}\text { Year of the Unicorn } \\
\text { status }\end{array}$ & $\begin{array}{l}\text { Time before reaching } \\
\text { the value of USD } 1 \\
\text { billion }\end{array}$ \\
\hline Jet.com & USA & July 2015 & E-commerce & November2015 & 4 months \\
\hline APUS Group & China & June 2014 & Software & January 2015 & 7 months \\
\hline Rong360 & China & March 2015 & Financial services & October 2015 & 7 months \\
\hline BeiBei & China & April 2014 & E-commerce & January 2015 & 10 months \\
\hline Illumio & USA & June 2013 & Software & April 2014 & 1 year \\
\hline Iwjw & China & June 2014 & Real estate & June 2015 & 1 year \\
\hline Lashou.com & China & March 2010 & E-commerce & March 2011 & 1 year \\
\hline 58 Daojia & China & September 2014 & $\begin{array}{l}\text { Internet technology for end } \\
\text { users }\end{array}$ & October 2015 & 1 year 1 month \\
\hline Lamabang & China & December 2013 & $\begin{array}{l}\text { Internet technology for end } \\
\text { users }\end{array}$ & March 2015 & 1 year 3 months \\
\hline Uptake & USA & June 2014 & Analytics & October 2015 & 1 year 4 months \\
\hline WePiao & China & June 2014 & E-commerce & November 2015 & 1 year 5 months \\
\hline WeWork & USA & August 2012 & Real estate & February 2014 & 1 year 6 months \\
\hline Xiaomi & China & April 2010 & Hardware & December 2011 & 1 year 9 months \\
\hline $\begin{array}{l}\text { Oscar Health } \\
\text { Insurance CO }\end{array}$ & USA & July 2013 & Health care & April 2015 & 1 year 10 months \\
\hline
\end{tabular}

Please cite this article as: Butuzova A.S. Capitalization of International Unicorn Companies: To What Extent Is It Reasonable? 
A.S. Butuzova / Digest Finance, 2018, volume 23, issue 1, pages 63-67

\begin{tabular}{|c|c|c|c|c|c|}
\hline Carbon3D & USA & June 2013 & Manufacturing & August 2015 & 2 years \\
\hline Dada & China & June 2014 & $\begin{array}{l}\text { Internet technology for end } \\
\text { users }\end{array}$ & January 2016 & 2 years \\
\hline Fab & USA & June 2011 & E-commerce & August 2013 & 2 years \\
\hline Square & USA & June 2009 & E-commerce & January 2011 & 2 years \\
\hline ZhongAn & China & June 2013 & Financial services & June 2015 & 2 years \\
\hline zulily & USA & June 2010 & E-commerce & November 2012 & 2 years \\
\hline
\end{tabular}

Source:Authoring, based on Fleximize website data. URL: https://fleximize.com/

\section{References}

1. Malinina E.V. [The role of capitalization in the modern world economy]. Finansy $i$ kredit = Finance and Credit, 2011, no. 13, pp. 63-66. URL: https://cyberleninka.ru/article/v/rol-kapitalizatsii-v-sovremennoy-mirovoyekonomike (In Russ.)

2. Filatova A.S., Zhuk S.S. [Startups - Threats, Opportunities and Prospects for Corporations]. Aspirant, 2016, no. 8, pp. 116-120. (In Russ.)

3. Nazarov A.A. [Russian Venture Capital Market: Status and Trends]. Ekonomicheskie nauki = Economic Sciences, 2016, no. 139, pp. 48-52. (In Russ.)

4. Valdaitsev S.V. [An 'open' model to finance innovative start-ups]. Innovatsii = Innovations, 2011, no. 11, pp. 47-52. (In Russ.)

5. Litvintsev D.O. [IPO of the innovative company as the exit method from venture fund in Russia]. Sibirskaya finansovaya shkola = Siberian Financial School, 2016, no. 5, pp. 137-141. (In Russ.)

6. Babaev E.D., Zhuravlev A.Yu. [Startup as a venture capital investment object: Issues and features]. Science, Education, Society: Trends and Prospects: materialy 1 i mezhdunarodnoi nauchnoi konferentsii [Proc. 1st Int. Sci. Conf. Science, Education, Society: Trends and Prospects]. Los Gatos, Professional Science, 2016, pp. 29-34.

7. Nureev D.S. [Financial aspects of market value appraisal of the high-tech sectors companies]. Nauchnoe obozrenie $=$ Science Review, 2015, no. 20, pp. 327-340. (In Russ.)

8. Lugachev M.I. [Information revolutions, economics and economic education]. Vestnik Moskovskogo Universiteta. Seriya 6: Ekonomika = Moscow University Economics Bulletin, 2017, no. 4, pp. 142--160. (In Russ.)

9. Vyalov D.A. [Domestic IT-startups: Competitiveness in the global market]. Sodeistvie razvitiyu malogo i srednego predprinimatel'stva: zarubezhnyi opyt i rossiiskaya praktika = Promoting Small and Medium-Sized Businesses: Foreign Experience and Russian Practice, 2014, no. 1, pp. 153-158. (In Russ.)

10. Aleinikova O.I. [Startup as an irreversible way of business development]. Innovatsii v upravlenii regional'nym $i$ otraslevym razvitiem: materialy Vserossiiskoi s mezhdunarodnym uchastiem nauchno-prakticheskoi konferentsii [Proc. Sci. Conf. Innovation in Managing the Regional and Sectoral Development]. Tyumen, TIU Publ., 2014, pp. 21-24.

\section{Conflict-of-interest notification}

I, the author of this article, bindingly and explicitly declare of the partial and total lack of actual or potential conflict of interest with any other third party whatsoever, which may arise as a result of the publication of this article. This statement relates to the study, data collection and interpretation, writing and preparation of the article, and the decision to submit the manuscript for publication.

Please cite this article as: Butuzova A.S. Capitalization of International Unicorn Companies: To What Extent Is It Reasonable? 